\title{
Environmental reporting in South Africa from 1994 to 1999: $A$ research note
}

\author{
C J de Villiers \\ Department of Accounting \\ and Finance \\ University of Pretoria
}

\author{
P Barnard \\ Department of Accounting \\ and Finance \\ University of Pretoria
}

\begin{abstract}
The content of the annual reports of listed South African mining companies from 1994 to 1999 was analysed to determine how many disclose certain environmental information. This number, expressed as a percentage, was compared with the corresponding percentage disclosure among the Financial Mail Top 100 industrial companies for the same years. A greater number of mining companies, when compared to other large companies, disclose environmental information. This finding is consistent with legitimacy, which is the notion that an organisation will not continue to prosper if its aims and methods are in conflict with that of society. Mining companies have a greater need to legitimise their operations by means of environmental disclosure, because their environmental impact is extensive and obvious.
\end{abstract}

Key words

Environmental reporting

Environmental disclosure

Environmental accounting

Introduction, problem statement and outline of the paper

Environmental reporting has attracted increasing interest in South Africa in recent years, as evidenced by the establishment of two separate environmental reporting award schemes. The WWF makes annual awards for the best separate environmental reports, whereas KPMG in conjunction with the University of Pretoria makes annual awards to Johannesburg Stock Exchange (JSE) based on environmental reporting in their annual reports. KPMG also publishes a list each 
year of the top 50 companies in terms of environmental reporting in annual reports. The list is predominated by mining companies. For example, in the 1999 report (Visser \& De Villiers 1999:22), eight of the top ten companies are mining companies and 32 of the full list of 50 companies are mining companies.

International research has indicated that certain industries, such as the mining and larger companies consistently disclose more environmental information than smaller companies or companies in other industries (Gray et al 1995; Hackston \& Milne 1996). Some South African research evidence indicates concurrence with the view that industry is a good predictor of the extent of environmental reporting (Doppegieter \& De Villiers 1995; De Villiers \& Visser 1998). An Australian study (Deegan \& Rankin 1999) found that companies provide less environmental information than users expect, except in the mining sector, where companies appear to be more attuned to the information needs of stakeholders. Tilt \& Symes (1999) indicate that the reason that many Australian mining companies disclose "environmental" information, is that they disclose information in terms of rehabilitation provisions - a disclosure that is encouraged by income tax advantages.

This paper aims to establish whether mining industry companies in South Africa disclose more environmental information in their annual reports than other large listed companies.

In the next section of the paper, a theoretical framework is sketched. Following is a discussion of the method employed, including the types of reporting investigated. Then the results is presented and the article closes with a conclusion.

\section{Theoretical framework}

The notion of legitimacy has often been used as a framework in empirical social and environmental research (Gray et al 1995; Brown \& Deegan 1998; Adams et al 1998; Deegan \& Rankin 1997; Clarke \& Gibson-Sweet 1999). According to this notion of organisational legitimacy, an organisation cannot continue to thrive if its aims and operations are perceived to be in conflict with that of society.

Lindblom (1994) identified four strategies by means of which an organisation can use social or environmental reporting to legitimise itself:

1. Report to educate and inform (The organisation changes and reports the fact). 
2. Report to change perceptions (The organisation does not change, but reports what it does).

3. Report to manipulate perceptions (Positive news is emphasised and negative news ignored).

4. Report to change external perceptions (Expectations are seen as unfair).

Mining companies have a visible and obvious impact on the natural environment. It can, therefore, be expected that these companies will come under close scrutiny from environmental groups and other concerned citizens. This public pressure has the effect of questioning the legitimacy of the aims and operating procedures of mining companies. According to the notion of legitimacy, they will not be able to thrive under these circumstances. They will, therefore, be inclined to use all the means at their disposal, including environmental reporting, to legitimise themselves.

In summary, according to the notion of legitimacy, companies that have an obvious environmental impact, such as mining companies, are more likely to disclose environmental information in an effort to legitimise themselves than are companies that have a with less obvious impact, such as industrial companies.

\section{$3 \quad$ Method and questionnaire development}

This investigation is limited to listed companies, because it is difficult to obtain the annual reports of non-listed companies. The annual reports of all mining companies listed on the Johannesburg Stock Exchange (JSE) for the years ending from 1994 to 1999 are regarded as representative of South African for the purpose of establishing their environmental reporting practices. The aim of this paper is to establish whether mining companies report more than nonmining companies. Larger companies report more environmental information (see introduction) than smaller companies. Therefore, if the largest non-mining companies are used in the comparison and mining companies still report more than the large non-mining companies, it could be concluded that mining companies report more environmental information than all non-mining companies. For this reason, the annual reports of the Financial Mail Top 100 industrial companies (all JSE listed) for the above mentioned years are used in the comparison.

The annual reports were analysed with the aid of a questionnaire. The questionnaire was based on the "minimum requirements" suggested by De Villiers (1996), specifically the first 5 types recommended. The full "minimum requirement" is reproduced in Table 1 below. 


\section{Table 1: Recommended minimum requirements for corporate environmental reporting}

1. A descriptive overview of the major environmental risks and impacts of the organisation

2. The environmental policy of the organisation

3. Measurable targets in physical units and rand amounts, where applicable, based on the environmental policy, e.g. emissions

4. Performance compared to environmental targets and comparative figures (previous year)

5. Accounting policies for the recording of liabilities, provisions, contingent liabilities and catastrophe reserves

6. Environmental costs (energy; waste handling; treatment and disposal; legal compliance; packaging; fines; rehabilitation; recycling; etc) by category charged to operating expenses during the period

7. Rand amounts of environmental liabilities, contingent liabilities and reserves established in the current period

8. Government environmental grants received

9. Likely effect of environmental policy on future capital investment and earnings

10. Environmental litigation in which the organisation is currently involved

11. Independent third party attestation of all environmental reporting

SOURCE: De Villiers 1996:202

The first five items on the list of recommendations address the major environmental issues, whereas the final six items are of a more specific and detailed nature. The first five items provide an overview, whereas the final six deal with details. There is a natural distinction between the first five items and the final six and, therefore, it was decided to use only the broader first five types of environmental disclosure in this survey.

\section{$4 \quad$ Results and comments}

The number of mining companies included in the survey are indicated below: 


\begin{tabular}{|c|c|c|c|c|c|c|}
\hline & $\mathbf{1 9 9 4}$ & $\mathbf{1 9 9 5}$ & $\mathbf{1 9 9 6}$ & $\mathbf{1 9 9 7}$ & $\mathbf{1 9 9 8}$ & $\mathbf{1 9 9 9}$ \\
\hline Mining companies & 121 & 118 & 117 & 93 & 72 & 48 \\
\hline
\end{tabular}

The number of listed mining companies reduced over time as a result of several delistings and amalgamations.

The percentages of companies that disclosed the relevant environmental information are indicated separately below for the Financial Mail Top 100 industrial companies and the mining companies.

1 Is mention made of the environmental impacts and risks of the business?

\begin{tabular}{|l|c|c|c|c|c|c|}
\hline & $\mathbf{1 9 9 4}$ & $\mathbf{1 9 9 5}$ & $\mathbf{1 9 9 6}$ & $\mathbf{1 9 9 7}$ & $\mathbf{1 9 9 8}$ & $\mathbf{1 9 9 9}$ \\
\hline & Yes & Yes & Yes & Yes & Yes & Yes \\
\hline $\begin{array}{l}\text { Financial Mail Top } \\
100 \text { industrials }\end{array}$ & $14 \%$ & $10 \%$ & $14 \%$ & $27 \%$ & $21 \%$ & $24 \%$ \\
\hline Mining companies & $13 \%$ & $13 \%$ & $42 \%$ & $39 \%$ & $28 \%$ & $48 \%$ \\
\hline
\end{tabular}

A greater proportion of mining companies than top industrial companies disclosed their environmental impacts and risks in every year, except in 1994 when the difference was relatively small. An overall trend towards increased disclosure over the period is evident, with some reductions in specific years, such as in 1998. However, the differences in disclosure from year to year are not of interest in this paper, which deals only with the difference between mining and non-mining companies.

2 Does the corporate policy or mission statement mention a policy or mission regarding the environment?

\begin{tabular}{|l|c|c|c|c|c|c|}
\hline & $\mathbf{1 9 9 4}$ & $\mathbf{1 9 9 5}$ & $\mathbf{1 9 9 6}$ & $\mathbf{1 9 9 7}$ & $\mathbf{1 9 9 8}$ & $\mathbf{1 9 9 9}$ \\
\hline & Yes & Yes & Yes & Yes & Yes & Yes \\
\hline $\begin{array}{l}\text { Financial Mail Top } \\
100 \text { industrials }\end{array}$ & $19 \%$ & $21 \%$ & $18 \%$ & $22 \%$ & $22 \%$ & $31 \%$ \\
\hline Mining companies & $9 \%$ & $8 \%$ & $10 \%$ & $11 \%$ & $32 \%$ & $52 \%$ \\
\hline
\end{tabular}

Relatively more top industrial companies disclosed a policy or mission statement that included a policy or mission regarding the environment in the years 1994 to 1997. However, in 1998 and 1999 mining companies took the lead. It can only be speculated what the reason was for the lesser disclosure of mining companies in earlier years. An explanation, that would be consistent with the notion of legitimacy, could be that in earlier years the general public 
or society was not as aware of the impact of mining companies.

3 If environmental objectives are disclosed, do they set measurable standards, enabling environmental performance achieved to be compared with the objectives?

\begin{tabular}{|l|c|c|c|c|c|c|}
\hline & $\mathbf{1 9 9 4}$ & $\mathbf{1 9 9 5}$ & $\mathbf{1 9 9 6}$ & $\mathbf{1 9 9 7}$ & $\mathbf{1 9 9 8}$ & $\mathbf{1 9 9 9}$ \\
\hline & Yes & Yes & Yes & Yes & Yes & Yes \\
\hline $\begin{array}{l}\text { Financial Mail Top } \\
100 \text { industrials }\end{array}$ & $18 \%$ & $14 \%$ & $24 \%$ & $16 \%$ & $10 \%$ & $11 \%$ \\
\hline Mining companies & $23 \%$ & $27 \%$ & $46 \%$ & $63 \%$ & $25 \%$ & $29 \%$ \\
\hline
\end{tabular}

A larger proportion of mining companies than top industrial companies disclosed measurable targets in every year of the survey. The major reduction in the percentage of mining companies that disclosed measurable targets in 1997 and 1998 is similar to the reduction noted in question 1.

4 Has the company disclosed whether it has achieved its objectives in respect of the environment?

\begin{tabular}{|l|c|c|c|c|c|c|}
\hline & $\mathbf{1 9 9 4}$ & $\mathbf{1 9 9 5}$ & $\mathbf{1 9 9 6}$ & $\mathbf{1 9 9 7}$ & $\mathbf{1 9 9 8}$ & $\mathbf{1 9 9 9}$ \\
\hline & Yes & Yes & Yes & Yes & Yes & Yes \\
\hline $\begin{array}{l}\text { Financial Mail Top } \\
100 \text { industrials }\end{array}$ & $17 \%$ & $17 \%$ & $18 \%$ & $20 \%$ & $22 \%$ & $22 \%$ \\
\hline Mining companies & $17 \%$ & $29 \%$ & $33 \%$ & $68 \%$ & $28 \%$ & $42 \%$ \\
\hline
\end{tabular}

Relatively more mining companies disclosed whether they met their own environmental targets in each of the years. There is again a major reduction in this type of disclosure in 1998.

5 Are the accounting policy notes regarding environmental accounting disclosed?

\begin{tabular}{|l|c|c|c|c|c|c|}
\hline & $\mathbf{1 9 9 4}$ & $\mathbf{1 9 9 5}$ & $\mathbf{1 9 9 6}$ & $\mathbf{1 9 9 7}$ & $\mathbf{1 9 9 8}$ & $\mathbf{1 9 9 9}$ \\
\hline & Yes & Yes & Yes & Yes & Yes & Yes \\
\hline $\begin{array}{l}\text { Financial Mail Top } \\
100 \text { industrials }\end{array}$ & $4 \%$ & $5 \%$ & $5 \%$ & $7 \%$ & $5 \%$ & $5 \%$ \\
\hline Mining companies & $12 \%$ & $20 \%$ & $36 \%$ & $52 \%$ & $57 \%$ & $60 \%$ \\
\hline
\end{tabular}


Relatively more mining companies disclosed environmental accounting policy notes in each of the years. This is understandable, because mines usually have rehabilitation liabilities that must be met at the end of the useful life of the mine. Companies have to provide for rehabilitation and disclose their accounting policy in this regard (compare Tilt \& Symes 1999). A greater percentage of mining companies disclosed accounting policy notes in each of the years covered by the survey.

The reductions in disclosure in 1998, noted in questions 1, 3 and 4, may be the result of a fear of possible environmental liability experienced by certain companies. The percentage of companies that disclosed their environmental policy (question 2) or their environmental accounting policy notes (question 5) did not reduce in 1998. The former is probably too general in nature to increase the possibility of liability and the latter is an accounting policy that has no influence on liability. In contrast, disclosing risks and impact, measurable targets and performance against targets has the potential of alerting stakeholders to adverse environmental impacts and operations of the company that could lead to litigation against the company. This is pure conjecture and more research is needed to establish the true reason for the apparent reduction in specific types of environmental disclosure in 1998.

\section{Conclusions}

There is evidence of industry differences in environmental reporting in South Africa. Mining companies have a very clear and visible impact on the natural environment. A greater proportion of mining companies disclose each type of information in each annual report included in the survey than do the FM Top 100 industrial companies, except:

- Impacts and risks (question 1) in 1994, and

- $\quad$ Policy (question 2) in 1994, 1995, 1996 and 1997.

A possible explanation for this phenomenon is that the average size of mining companies might have been smaller than that of the FM Top 100 industrials during the earlier years of the survey. However, the average size of mining companies may have increased in the latter years of the survey as a result of the many amalgamations that occurred in the industry. Larger companies have a greater tendency to report environmental information than smaller companies, as mentioned in section 1 .

It can be concluded from this survey that listed mining companies in South Africa disclose more environmental information in their annual reports than other large listed companies. This finding is consistent with the notion of legitimacy, because mining companies have a visible and obvious adverse effect on the environment and they could be expected to attempt to legitimise 
their operations through more environmental disclosure to a greater extent than other large companies.

\section{Bibliography}

Adams, C.A., Hill, W.Y. \& Roberts, C.B. 1998. Corporate social reporting practices in Western Europe: Legitimating corporate behaviour?, British Accounting Review, Vol. 30, No. 1, pp.1-22.

Brown, N. \& Deegan, C. 1998. The public disclosure of environmental performance information - a dual test of media agenda setting theory and legitimacy theory, Accounting and Business Research, Vol. 29, No. 1, pp.2141.

Clarke, J. \& Gibson-Sweet, M. 1999. The use of corporate social disclosures in the management of reputation and legitimacy: A cross sectoral analysis of UK Top 500 companies, Business Ethics: A European Review, Vol. 8, No. 1, pp.513.

De Villiers, C.J. 1996. The awareness level of different stakeholder groups and their willingness to support corporate environmental reporting in South Africa, Unpublished Doctor of Commerce dissertation, University of Pretoria, Pretoria.

De Villiers, C.J. \& Visser, W. 1998. Survey of environmental reporting in South Africa, fifth edition, KPMG and University of Pretoria, Cape Town.

Deegan, C. \& Rankin, M. 1999. The environmental reporting expectations gap: Australian evidence, British Accounting Review, Vol. 31, No. 3, pp.313-346.

Deegan, C. \& Rankin, M. 1997. The materiality of environmental information to users of annual reports, Accounting, Auditing and Accountability Journal, Vol. 10, No. 4, pp.562-583.

Doppegieter, J.J. \& De Villiers, C.J. 1995. Environmental reporting practices in the South African energy sector, Management Dynamics, Vol. 5, No. 1, pp.15-42.

Gray, R., Kouhy, R. \& Lavers, S. 1995. Corporate social and environmental reporting: A review of the literature and a longitudinal study of UK disclosure, Accounting, Auditing and Accountability Journal, Vol. 8, No. 2, pp.47-77. 
Hackston, D. \& Milne, M. 1996. Some determinants of social and environmental disclosures in New Zealand companies, Accounting, Auditing and Accountability Journal, Vol. 9, No. 1, pp.77-108.

Lindblom, C. 1994. The implications of organisational legitimacy for corporate social performance and disclosure, paper presented at the Critical Perspectives on Accounting Conference, New York, N.Y.

Tilt, C. \& Symes, C. 1999. Environmental disclosure by Australian mining companies: Environmental conscience or commercial reality?, Accounting Forum, Vol. 23, No. 2, pp.137-154.

Visser, W. \& De Villiers, C.J. 1999. Survey of environmental reporting in South Africa, sixth edition, KPMG and University of Pretoria, Cape Town. 